392.

FCRの低コントラスト分解能（各注度領域におけるL值の影需）

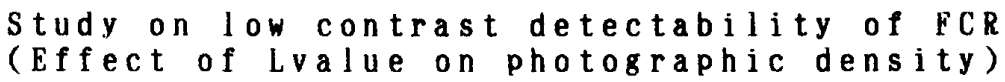

【目的】

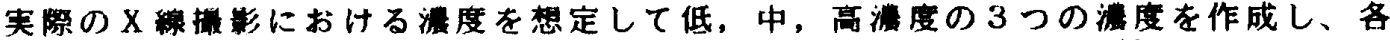
港度の低コントラスト分解能をFCRとScreen/Fil田システムで比䖝する。

またFCRはL值在 $1 ， 2 ， 3 ， 4$ と変化させて比行う。

\title{
【方法】
}

Screen/トillはRQ/Cronex10をFCRのイメージングブレートはST-3を使用した。

1 回のX緗明射で3つの湍度ができるように铜板とアクリルを用いてファントムを作

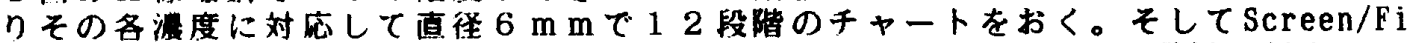

Imで中源度部が 1 。 0 となるように晿射し、全く同条件で F C R の时を射をう。

F CRの取り䢋みはF i x モードS俌 200 で行い特性曲線をScreen/Filmと同じに

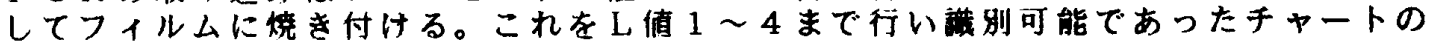

数を調べる。

【結果】

1. 低源度部ではFCRの淈度が低いためScreen/filmのほうが良い結果となった (Fig.1)か、浱度を问じにするとFCRのほうが良かった。（Fig.4）

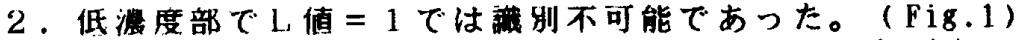

3. 低㵊度部ではL值の大きいほど良い結果となったが中・高淡度部ではほとんど変 わらなかった。(Fig.1,2,3)

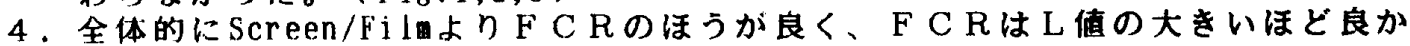
つた。(Fig.1,2,3,4)

\section{【結訟 】}

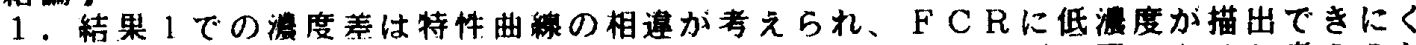

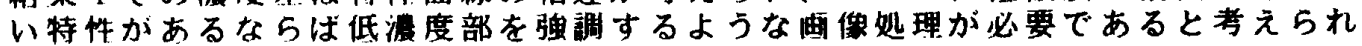
る。

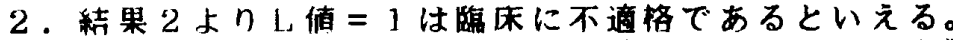

3. 結果 3,4 より臨床においてL值を大きくとっても問题ないものと考えられる。

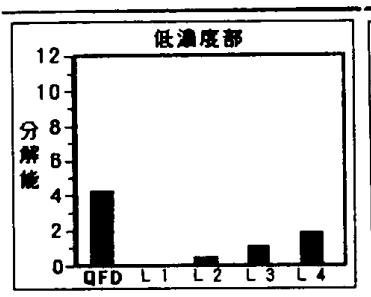

Fis 1

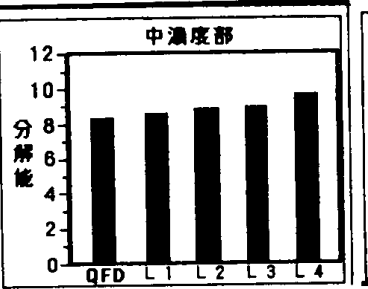

Fig 2

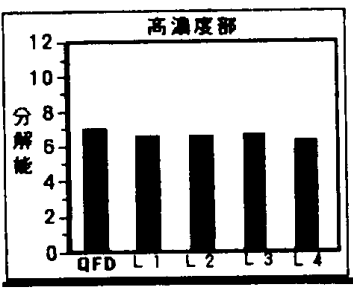

F i 83

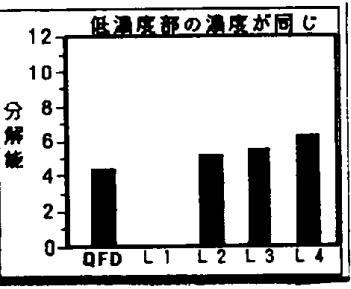

F i 84 